\title{
The Analysis of Legal Education Practical Reform Based on The Social Position of Law
}

\author{
Tao Tao \\ Lecturer of The Law School of Beihua University, Jilin,Jilin Province,China
}

Keywords: Education of law, The rule of law, Practice, Social science of law.

\begin{abstract}
With the development of the rule of law, the law education also faces the reform of living in the time and solving practical problems. Based on the legal position of social science, this paper analyzes the background and reality of education in the present law, and puts forward the orientation, core content and specific measures of the reform of the law education, and points out that the law education should be fully oriented towards practice. In order to solve the problem of education and social practice, we should focus on the reform of teaching method and reform of teaching methods, and finally realize the progress of teaching effect, which is to focus on solving the distance between the law education and social practice, so that education can cultivate legal professionals with legal career thinking and practical problem solving.
\end{abstract}

\section{Introduction}

The discussion between legal dogmatic and social science of law in domestic recently can be regard as a new tendency of the development of legal science. The two factors that contemporary Chinese characteristics of the time and the complex relationship between law and society overlay form the background of research in legal science. The localization tendency of legal research constitutes the context of the confrontation. " ${ }^{[1]}$ Mainly affected by the traditional American law, social law emphasizes the use of social science approach to the study of legal phenomena, on the basis of empirical research, pay attention to the approach of causal interpretation, through empirical research to understand the problem; mainly affected by the traditional German law, legal dogmatic emphasizes the systematic, emphasize on the basis of the legal text and creed, pay attention to the legal norms and the interpretation of the relationship between norms and facts, pay attention to the realization of the value of legal norms." In this paper, we will put forward the specific understanding of law education reform based on the social position of law and respond to the pursuit of the rule of law era.

\section{The Status Quo of Law Education}

The present situation of the current legal education is, still stay in based on the theory of continental law system or Anglo-American law system, path dependence for imparting knowledge system already, and no real starting from the establishment of the socialist legal system with Chinese characteristics, and pay more attention to the reality of knowledge. It is a direct result of the legal science specialized students generally feel the disconnection between knowledge and practice, learn from use. Solving this problem is complete in the true sense of the key to legal science specialized higher education goal. No longer simply do old ideas convey but contribute to the production of new ideas, no longer simply teach but the cultivation of the ability to apply the theoretical knowledge, no longer let legal professional group but row over the system to solve specific problems under the system. Truly cultivate rational, critical professional spirit and professional ethics, and the theoretical accomplishment into practice ability and practice effect of the student, from law education to update of law education. 
Living with age, even beyond the development of the times, both in teaching contents and teaching methods, even more importantly on the teaching method and realizing the law subject education system and the current law system, institution system, the correspondence of the rule of law system should become to the backbone of law education reform should take. Since 1998, in addition to a small number of political and law major institutions, the university of China has carried out the "big law" education, which is not subject to the discipline of the university. The professional backbone courses are clearly defined by the education competent authority. Basic teaching is the primary and even the only teaching method. The proportion of practice teaching and practice are very small or in form. Among them, the implementation of "law" equal to education in three and a half years time to complete four years of at least 30 above the door of professional courses, the average intensity of each year of study in the 10 or so door. The vast majority of colleges and universities will be configured at the class specialized backbone course setting of 48-96 hours, set the professional courses for 30 to 40 hours, and only a handful of colleges and universities of political science and law or 985 colleges and universities take a real sense of professional courses, most of the other professional elective courses means that professional required course in university. The corollary is that most courses are not taught in the prescribed time, and there is no time for practical teaching. For example, the law of litigation, with the substantial revision of the procedural law in recent years, has added a lot of content to the professional teaching, but the amount of class has not changed with it. If knowledge is not taught, students will not master naturally. Second, the education authorities explicitly identify professional backbone courses. Except for a few specialized colleges and universities of political science and law have clear categories and in a planned way has direction of classified teaching for students according to their own interest, ability, knowledge selection, most colleges and universities implement the same quantitative product mode of education, even has developed to the point of teaching material use almost the same. Initially, the aim of the core curriculum of law major was to emphasize the basic status and importance of these 16 courses, rather than to require the teaching contents of sixteen courses to be consistent. This phenomenon is not conducive to the development of law profession itself, and it is not conducive to the cultivation of legal professionals. Coupled with the judicial examination pass rate of utilitarian considerations, students learn not beyond the law text, knowledge is not out of the classroom, ability from the examination paper. The result is in creating the judicial examination pass rate under the surface of the brilliant. In the face of the present situation of education, we can define the method of law education under the guidance of doctrine. When we still immersed in the hope that the theory will guide practice, higher education and social development have been reversed transmission requirements keep up with the times, overall rise enough to prove that vocational education in recent years, more pressing social demand is the practice rather than theory model, so the education of law should pay more attention to practical support theory. The era of social development reveals that the law major education: first, it should put forward to keep up with the times and even surpass the needs of the times. Second, it must grasp the principle and the soul, have the discipline own accurate value positioning, political position; thirdly, education of law should also shift from cultivating students' understanding ability to the cultivation of theoretical and practical analytical ability and practical ability. The present situation of education, which has been clearly presented, has given the direction, thought and even content of the reform of education.

\section{The Necessity of The Law Education to The Practice}

The law education should be fully turned towards the practice of Chinese construction in line with the rule of law.

With China under the rule of law as a system of legal theory is to focus on the judicial practice, pay attention to the rule of law government, society and country under the rule of law construction of rule of law, to solve the essence of the rule of law, the value of the rule of law and the rule of law culture, the rule of law, the rule of law thinking way, the authority of the constitution and the law, the rule of law and governance, rule of law and social governance, power supervision and restraint 
of integrating scientific research and teaching of the discipline theory system. Therefore, the legal theoretical system under the rule of the rule of law must not be a simple abstract theoretical system, but it should be based on reality, solve practical problems and face social development. This requires a change of existing way of the doctrine of socialist culture, based on the reality of reasonable theory, make the theory of fresh, can help solve the problem of reality is a vital theory, theory study also shall be conducted based on the consideration of the reality. In addition, "China" rule of law include the rule of law spirit, the connotation of the rule of law culture, the rule of law in seemingly abstract thinking, even if the spirit, culture and thinking would be into a complete theory, also should be established on the basis of social cognition and respond to the rule of law "reality". So in containing the government under the rule of law, rule of law society, the rule of law and governance, the rule of law and social governance and the spirit of the rule of law, the rule of law culture, the rule of law thinking of Chinese, rule of law theory is no hypothetical theory breaks away from practice.

\section{The Key Factor of The Law Education Transformation}

Transformation of Teacher Roles. As a professional teacher, he is no longer carry the "hypothesis" that law is law which is not related to other social realities, and simply consider the teaching method of legal issues. The Core of the reform should be the reform of teacher, should be the teacher's education idea, the teacher education mode, teaching content reform make teachers have the theoretical system of the social reality of diversified, on the basis of the social reality of divergent, practical teaching ability. "The duties of a teacher... He will increasingly become a consultant, an exchange participant, a man who helps to find contradictory arguments rather than to bring out the truth. He must focus on more time and energy on productive and creative activities: interaction, discussion, motivation, understanding, and inspiration. " [2] The law education reform is a process that start from teachers, from improving teacher's own theoretical system to contribute to the change of teachers' teaching content, then to complete nature innovation of teaching methods.

Reform of teaching methods. Teaching method reform is the means. They aim at teaching philosophy, teaching content, teaching effect, which ultimately to get the effect of half the work rather than the multiplier effect. New teaching methods should be accompanied by new teaching ideas and content, which should serve the new teaching idea and content. If the new teaching method is used to carry out the teaching content of old teaching ideas, it is a waste of education resources. In the world of law education, a law school that trains students to "think like lawyers", German law school proposes to train students to "think like a judge". Case teaching and clinic teaching methods are popular in Europe and the United States, which reflects the importance of the west to the cultivation of professional competence based on legal thinking. In order to overcome its shortcomings, Chinese law education has also begun to carry out case teaching attempts and introduced the teaching methods of legal clinics in the Anglo-American law system. In recent years we try to carried on the reform of course that have strong theoretical jurisprudence. Such as Jilin University "legal theory of life" course, a certain extent changed the single mode of theory teaching, cultivate students' vocational thinking played a role.

The advent of the era of Mobile Internet changes the phenomenon that take the single course knowledge system for the teaching content. Now we start the change that use the multimedia teaching method, increase the data use, make full use of good professional database, try to cross the legal department, the interdisciplinary knowledge teaching Angle; increase the practical teaching content, increase the proportion of moot court teaching, try to practice teaching mode, a large number of increasing practice hours, giving credit evaluation by internship units, let the students become the leading role of knowledge, let the teachers take a back seat, maintainer as classroom order, leader of the teaching content.

\section{Summary}

These are the thinking above mentioned in this paper. Down-to-earth is the most critical reform 
issue that should be solved by the present law education. Education teaching reform is an eternal topic, education has been in the process of development.Therefore, the law of social science education position should be regarded as an important thing.

\section{References}

[1] Gong Chunxia. Competition and cooperation: transcend disciplines within the walls - "law and the law doctrine study dialogue" seminar reviews [N]. Guangming daily, 2014-6-18 ,p16.

[2]UNESCO international education development committee. Learn to live [M]. Beijing: education science press, 1996,p108. 